\title{
Inhibin secretion after treatment with an LHRH agonist and subsequent ovarian hyperstimulation induced by FSH in the macaque (Macaca arctoides)
}

\author{
H. M. Fraser, K. B. Smith, K. Reddi* and S. F. Lunn \\ $M R C$ Reproductive Biology Unit, and *Department of Obstetrics and Gynaecology, University of \\ Edinburgh, Centre for Reproductive Biology, 37 Chalmers Street, Edinburgh EH3 9EW, UK
}

\begin{abstract}
Summary. The effect of ovarian hyperstimulation with 'pure' FSH on serum concentrations of immunoreactive inhibin in macaques in which endogenous gonadotrophin secretion and ovarian activity had been suppressed by an LHRH agonist implant was studied. Four stump-tailed macaques were treated with an LHRH agonist implant in the early follicular phase of the cycle. After a transient stimulatory phase oestradiol secretion was markedly suppressed, and the rises in progesterone and inhibin observed after ovulation were absent. At 8 weeks after implant administration, when serum LH was only just detectable, FSH (Metrodin) was adminstered to the LHRH agonisttreated macaques once daily for 9 days (75 i.u. on Day 0,35 i.u. Days 1-8). FSH treatment stimulated a marked increase in oestradiol and immunoreactive inhibin secretion in the absence of a rise in serum progesterone concentrations. Comparison of the FSHinduced pattern of inhibin secretion with the profile during the normal menstrual cycle showed that during the normal cycle inhibin is secreted into the peripheral blood almost exclusively during the luteal phase in the macaque, but stimulation of follicular development by exogenous FSH was associated with a rise in inhibin concentrations in the absence of ovulation. These results suggest that this non-physiological rise in inhibin may be one of the factors involved in the changes in endogenous gonadotrophin secretion which can occur during ovarian hyperstimulation.
\end{abstract}

Keywords: FSH; oestradiol; inhibin; menstrual cycle; macaque; LHRH agonist

\section{Introduction}

The development of radioimmunoassays to measure circulating concentrations of inhibin by using antibodies raised against the native molecule or synthetic peptides from the $\alpha$ subunit has led to studies into the changes in blood concentrations of immunoreactive inhibin during different reproductive states. However, the role of inhibin during the normal menstrual cycle and during the course of regimens to induce ovarian hyperstimulation remains to be elucidated. Originally, inhibin was thought to be produced by the developing follicle to suppress selectively the secretion of pituitary follicle stimulating hormone (FSH); however, in women (McLachlan et al., 1987; Buckler et al., 1988) and in the stump-tailed macaque (Fraser et al., 1989), serum concentrations of immunoreactive inhibin are highest during the luteal phase.

Ovarian hyperstimulation by exogenous gonadotrophins is widely used both in women and in monkeys to obtain large numbers of oocytes for use in fertilization programmes (Boatman et al., 1986; McLachlan et al., 1986; Messinis \& Templeton, 1987, 1989; Glasier et al., 1988; Tsonis et al., 1988). There are indications that stimulation of the ovary in this way can induce alterations in the normal positive feedback relationship between oestradiol and the pituitary. The incidence of an LH surge is reduced and its magnitude is always attenuated. It has been suggested that this adverse 
effect is brought about by a non-steroidal product of the developing follicles (Schenken \& Hodgen, 1983; Stillman et al., 1983; Littman \& Hodgen, 1984; Messinis \& Templeton, 1987, 1989). In this study we have used exogenous FSH to induce follicular hyperstimulation in the stump-tailed macaque. The effects of this treatment on immunoreactive inhibin concentrations in peripheral blood were compared to the situation found during the normal cycle. Before FSH treatment, follicular development and ovulation were suppressed by inducing pituitary desensitization with an implant of an agonist of luteinizing hormone-releasing hormone (LHRH) (Fraser et al., 1987; Fraser \& Lunn, 1989). This permitted synchronization of the timing of the stimulatory treatment and restricted our observations to follicular development by avoiding the induction of ovulation which is known to be associated with an elevation in inhibin concentrations.

\section{Materials and Methods}

Control cycles. Ten adult female stump-tailed macaques (Macaca arctoides) weighing 9-14 kg were used. Details of their management have been published previously (Fraser et al., 1986). The animals had exhibited regular menstrual cycles with normal luteal phases as determined by hormonal estimations 3 times per week, fulfilling the criteria described previously (Fraser et al., 1986). Blood samples $(4 \mathrm{ml}$ ) were collected daily by femoral venepuncture without anaesthesia beginning during the early follicular phase and continuing until the end of the cycle. The blood was centrifuged at $1000 \mathrm{~g}$ for $20 \mathrm{~min}$, the serum divided into two aliquots and stored at $-20^{\circ} \mathrm{C}$ until assayed for progesterone, oestradiol- $173, \mathrm{LH}$ and inhibin.

LHRH agonist implant. Four adult female stump-tailed macaques with regular menstrual cycles each received a single implant containing $3 \mathrm{mg}$ buserelin ([D-Ser (tBu)6,Pro9-NHEt] LHRHl-9 (Dr J. Sandow and H. Seidel, Hoechst AG, Frankfurt, FRG). The implants were made of slowly biodegradable polylactic/glycolide (molar ratio 75 : 25) sterilized by gamma radiation. The LHRH agonist implant was administered during the early follicular phase of the cycle as described previously (Fraser et al., 1987). The macaques were sedated using ketamine hydrochloride (Vetalar: Parke, Davis and Co., Pontypool, Gwent, UK) and the implant was injected s.c. in the lateral region of the abdominal wall using a sterile applicator. Blood samples were collected at least 3 times per week thereafter.

LHRH test. At 1 week before the treatment with FSH, an LHRH test was performed by i.v. injection of $50 \mu \mathrm{g}$ LHRH (Gonadorelin: Ayerst Laboratories Ltd, Andover, Hants, UK). Blood samples were collected at 0, 30 and $60 \mathrm{~min}$. The test was repeated on the final day of FSH treatment. Results were compared with those obtained after carrying out the same LHRH test in 6 control animals during the early follicular phase of the normal cycle.

FSH treatment. At 8 weeks after receiving the implant, the macaques were treated with FSH (Metrodin: Serono Laboratories, Welwyn Garden City, Herts, UK) in $1 \mathrm{ml} 0.9 \%$ w/v sodium choride solution i.m. once daily for 9 days (75 i.u. on Day 0, 35 i.u. on Days 1-8).

Assays. Serum LH concentrations during the LHRH tests were determined using an in-vitro bioassay based on the production of testosterone by dispersed mouse Leydig cells as described previously (Fraser et al., 1986). Sensitivity of the assay was $1.0 \mathrm{ng} \mathrm{LH}$ (NICHHD rhesus monkey pituitary standard RP-1)/ml. Inter- and intra-assay coefficients of variance were 15 and $11 \%$ respectively. To determine the day of the preovulatory $\mathrm{LH}$ surge, serum LH was measured by radioimmunoassay (Fraser et al., 1987).

Progesterone was determined as described previously (Fraser et al., 1986) using a rabbit antibody R31. Sensitivity of the assay was $0.2 \mathrm{ng} / \mathrm{m}$ land inter-and intra-assay coefficients of variance were 15 and $4 \%$ respectively. Oestradiol-17 7 was measured using a sheep antibody provided by Dr B. A. Morris (Land et al., 1982). Sensitivity of the radioimmunoassay was $20 \mathrm{pg} / \mathrm{ml}$ and inter- and intra-assay coefficients of variance were 11 and $5 \%$ respectively.

Inhibin concentrations were determined by a heterologous radioimmunoassay as described previously with minor modifications (Fraser et al., 1989). The assay utilized a rabbit antiserum (no. 1989) raised against purified bovine inhibin of $M_{\mathrm{r}} 31000$ and iodinated bovine inhibin of $M_{\mathrm{r}} 31000$ as tracer. Because a macaque inhibin preparation is not available samples of follicular fluid obtained from patients undergoing follicular stimulation for in-vitro fertilization were used. The potency of this material was assessed by comparison with a partly purified human follicular fluid inhibin preparation of biopotency $26 \pm 1.2 \mathrm{U} / \mathrm{ml}$ (mean \pm s.e.m.). The bio- and immunoactivity of the standard and details of the radioimmunoassay specificity have been reported elsewhere (Robertson et al., 1988a, b). Inhibin subunits obtained after reductive alkylation as well as other inhibin-related proteins show limited cross-reaction in the assay (Robertson et al., 1988b). The pro region of the $\alpha$-subunit precursor, disulphide linked to the mature $\alpha$ subunit (pro- $\alpha$ C), cross-reacts $288 \%$ in the RIA, but is not biologically active (Robertson et al., 1989). The presence of this protein, isolated from bovine follicular fluid, has not been demonstrated in the circulation or in biological fluids from other species.

In the radioimmunoassay the human serum stock gave a dose-response curve parallel to that for serum from female stump-tailed macaques, as judged by the lack of significant differences in the slopes of the logit-log doseresponse curves. The volume of serum in each tube was made up to $100 \mu \mathrm{l}$ by addition of serum from post-menopausal 
women which contained undetectable concentrations of inhibin. Substitution of the post-menopausal serum with serum from 2 stump-tailed macaques castrated 2 weeks previously produced identical standard curves. All samples were assayed in duplicate at $100 \mu 1$ in two assays with an inter-assay variation of $4 \%$. The within-assay variance, as assessed by the average index of precision, was 0.035 . The detection limit of the assay was $7.5 \mathrm{mU} / \mathrm{tube}$ or $75 \mathrm{mU} / \mathrm{ml}$ as expressed by $>2 \mathrm{~s}$.d. from the mean maximum binding.

\section{Results}

Serum concentrations of oestradiol, progesterone and inhibin, centred around the day of the midcycle LH surge (Day 0) in 10 control animals, are shown in Fig. 1. Inhibin concentrations were low during the follicular phase in all animals before the onset of a sustained rise from Day 4 or 5 after the LH surge. Levels of inhibin increased to maximal values during the mid-luteal phase before falling as the luteal phase came to an end.

The injection of the LHRH agonist implant induced a transitory rise in oestradiol and inhibin (Fig. 1). Thereafter, buserelin-implanted animals had low serum concentrations of inhibin, similar to those found during the early-mid follicular phase of the cycle and oestradiol was suppressed to early follicular-phase values (Fig. 1).
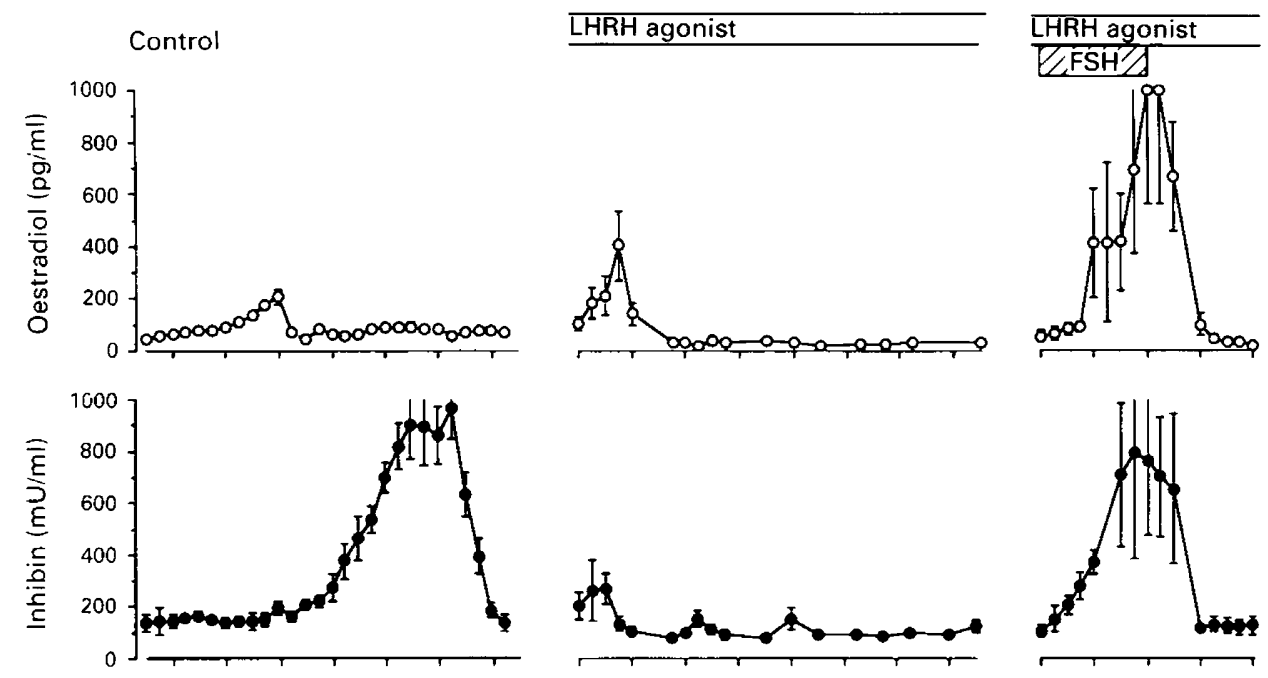

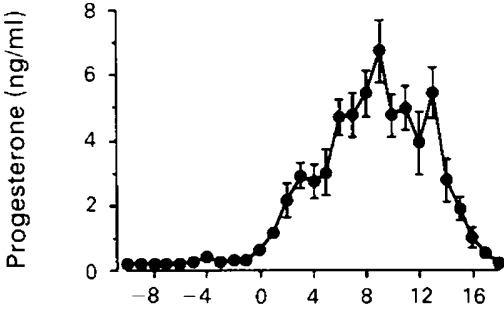

Day from LH surge

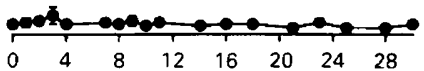

Day after implant

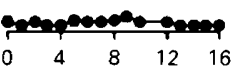

Day of FSH treatment

Fig. 1. Serum concentrations of progesterone, oestradiol and inhibin in 10 control macaques (data centred around the time of the pre-ovulatory LH surge (Day 0 )), in 4 macaques after treatment with an LHRH agonist implant starting during the early follicular phase and in the same animals after treatment with daily i.m. injections of FSH from Days 0 to 8 . Values are plotted as the mean \pm s.e.m. 
In the 6 control animals receiving an LHRH test during the early follicular phase of the cycle, serum $\mathrm{LH}$ concentrations increased from $18 \cdot 1 \pm 3 \mathrm{ng} / \mathrm{ml}$ at time 0 to $39 \cdot 3 \pm 6 \cdot 7$ and $34 \cdot 2 \pm$ $4 \cdot 1 \mathrm{ng} / \mathrm{ml}$ at 30 and $60 \mathrm{~min}$ respectively. In contrast, in animals treated with LHRH agonist implant and challenged acutely before the administration of $\mathrm{FSH}$, serum $\mathrm{LH}$ concentrations were around the detection limit of the LH bioassay $(1.7 \pm 0.6 \mathrm{ng} / \mathrm{ml})$ at time 0 , rising to $5.8 \pm 3.2 \mathrm{ng} / \mathrm{ml}$ and $5 \cdot 1 \pm 2 \cdot 6 \mathrm{ng} / \mathrm{ml}$ at 30 and $60 \mathrm{~min}$. This small rise was attributable to a response in one animal (No. 85).

The treatment with FSH resulted in marked rises in serum concentrations of inhibin and oestradiol beginning 3-4 days after starting treatment (Fig. 1). There was considerable individual variation in response as shown in Fig. 2, but the pattern of oestradiol and inhibin response was similar, the correlation between inhibin and oestradiol being $r=0.871(P<0.001)$ (Fig. 2).

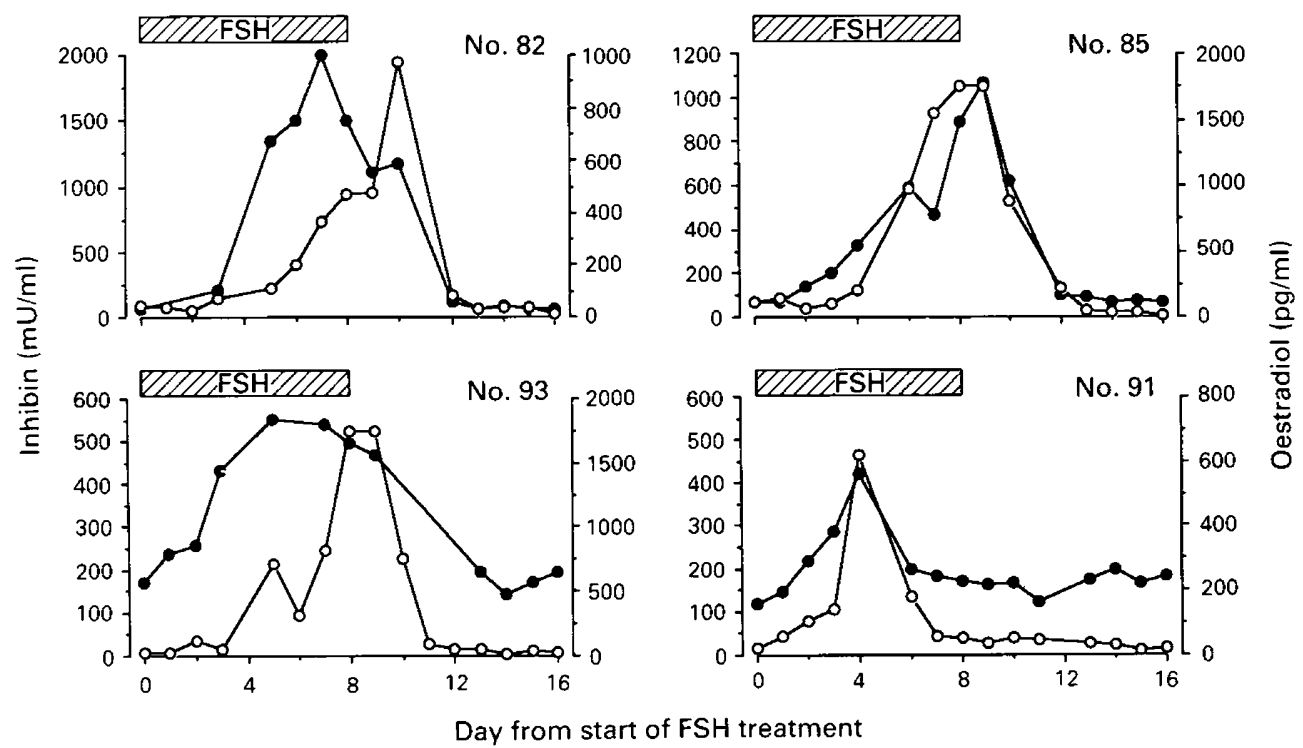

Fig. 2. Serum concentrations of oestradiol $(O)$ and inhibin $(O)$ in 4 macaques in which ovarian function was suppressed by an LHRH agonist implant (details Fig. 1) and subsequently treated with daily i.m. injections of FSH from Days 0 to 8.

On the last day of treatment with FSH, basal $\mathrm{LH}$ concentration was still around the detection limit of the assay, $2 \cdot 1 \pm 0.2 \mathrm{ng} / \mathrm{ml}$, and virtually no response was obtained to the LHRH test, $\mathrm{LH}$ concentrations being $3.2 \pm 0.2$ and $2.5 \pm 0.5 \mathrm{ng} / \mathrm{ml}$ at 30 and $60 \mathrm{~min}$, respectively. After cessation of FSH treatment, serum concentrations of inhibin and oestradiol declined (Fig. 2). The LHRH agonist implant maintained suppression of ovarian activity in the animals for a further 8 weeks, ovulation occurring $19.9 \pm 1.3$ weeks (mean \pm s.e.m.) after starting treatment.

\section{Discussion}

The secretion of immunoreactive inhibin into the peripheral blood during the normal cycle occurred predominantly during the luteal phase, following a pattern of secretion similar to that of progesterone and confirming previous reports in the macaque (Fraser et al., 1989) and in women (McLachlan et al., 1987; Buckler et al., 1988). Treatment with the LHRH agonist caused a suppression of serum inhibin and oestradiol concentrations, confirming the suppression of follicular

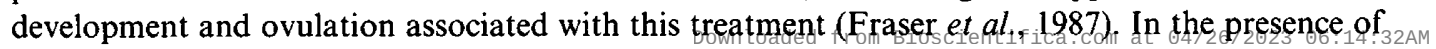


extremely low serum LH concentrations, FSH treatment induced follicular hyperstimulation in the agonist-implanted animals, resulting in a marked rise in serum inhibin concentrations associated with an elevation in oestradiol secretion. The correlation between inhibin and oestradiol concentrations in the absence of luteal progesterone secretion is a strong indication that the developing follicles are the source of the inhibin. Such a relationship would be in accord with earlier observations in women receiving exogenous $\mathrm{LH}$ and $\mathrm{FSH}$ combination regimens to induce ovarian hyperstimulation (McLachlan et al., 1986; Buckler et al., 1988; Tsonis et al., 1988) and would be expected from the 'classical' concept of inhibin being predominantly a product of the granulosa cells of the developing follicle (Channing et al., 1982). However, it seems that it requires growth of multiple antral follicles to induce the marked rises in serum inhibin during the period of follicular development, suggesting that the increase is an amplification of the small rise in serum inhibin observed during the late follicular phase of the normal cycle (Tsonis et al., 1988).

Studies of macaques and women receiving gonadotrophin treatment to induce ovarian hyperstimulation have revealed an attenuation or inhibition of the LH surge, decreased responsiveness to LHRH, and prevention of ovulation (Schenken \& Hodgen, 1983; Littman \& Hodgen, 1984; Messinis \& Templeton, 1987, 1989). It has been suggested that these inhibitory effects are the result of the production of a gonadotrophin surge inhibitory factor which is peptidic in nature (Stillman et al., 1983). Although it was thought originally that this substance might be inhibin, the demonstration of a substance in extracts of pig and human follicular fluid which suppressed LHRHstimulated LH and FSH release was in contrast to the effects of an inhibin preparation which suppressed FSH selectively in an in-vitro bioassay. Since the substance with these properties also had different physico-chemical characteristics from inhibin this suggested the presence of an additional gonadotrophin surge inhibitory factor (Danforth et al., 1987; Fowler et al., 1989).

The exact nature and biological role of the immunoreactive inhibin detected in the present study remains to be elucidated. This radioimmunoassay has demonstrated good correlation with an invitro sheep pituitary bioassay for inhibin (Robertson et al., 1988a), but macaque serum had a toxic effect on this bioassay system and so the bioactivity of the macaque samples could not be determined.

In conclusion, it is apparent that a number of substances are pharmacologically elevated in blood by hyperstimulation protocols and our results emphasize the non-physiological nature of the rise in inhibin resulting from the induction of follicular hyperstimulation following FSH treatment. Although the feedback role of inhibin during the normal menstrual cycle has yet to be elucidated, serum inhibin is likely to have a role in maintaining the low concentrations of FSH during the luteal phase. Further studies are required to examine the nature of the hypersecretion of inhibin during various regimens of follicular hyperstimulation and its role in altering feedback control of pituitary gonadotrophin release.

We thank G. M. Cowen, F. Khaleeli, K. Morris and K. Lamza for expert technical assistance; Dr C. M Howles (Serono Laboratories, UK) for the gift of Metrodin; Dr J. Sandow and H. Seidel (Hoechst AG, Frankfurt) for the gift of the LHRH agonist implants; and the NICHHD for the gifts of gonadotrophin preparations.

\section{References}

Boatman, D.E., Morgan, P.M. \& Bavister, B.D. (1986) Variables affecting the yield and developmental potential of embryos following superstimulation and in vitro fertilization in rhesus monkeys. Gamete Res. 13, 327-338.

Buckler, H.M., MacLachlan, R.I., McLachlan, V.B., Healy, D.L. \& Burger, H.G. (1988) Serum inhibin levels in polycystic ovary syndrome: basal levels and response to luteinizing hormone-releasing hormone agonist and exogenous gonadotropin administration. J. clin. Endocr. Metab. 66, 798-803.

Channing, C.P., Anderson, L.D., Hoover, D.G., Kolena, J., Osteen, K.G., Pomerantz, S.H. \& Tanabe, K. (1982) The role of nonsteroidal regulators in control of oocyte and follicular maturation. Recent Prog. Horm. Res. 38, 331-408.

Danforth, D.R., Sinosich, M.J., Anderson, T.L., Yan Cheng, C., Bardin, C.W. \& Hodgen G.D. (1987) Downtoaded from Bioscientifica.com at $04 / 26 / 2023$ 06:14:32AM via free access 
Identification of gonadotropin surge-inhibiting factor (GnSIF) in follicular fluid and its differentiation from inhibin. Biol. Reprod. 37, 1075-1082.

Fowler, P.A., Messinis, I.E. \& Templeton, A.A. (1989) Gonadotrophin surge-attenuating factor (GnSAF) activity in human follicular fluid is different from inhibin. J. Reprod. Fert., Abstr. Ser. No. 4, 30, abstr.

Fraser, H.M. \& Lunn, S.F. (1989) Rapid inhibitory effects of an LHRH agonist implant on the oestrogen-induced LH surge and the induction of a defective luteal phase after an agonist-induced ovulation in the macaque. Hum. Reprod. 4, 506-512.

Fraser, H.M., Abbott, M., Laird, N.C., McNeilly, A.S., Nestor, J.J., Jr \& Vickery, B.H. (1986) Effects of an LH-releasing hormone antagonist on the secretion of LH, FSH, prolactin and ovarian steroids at different stages of the luteal phase in the stumptailed macaque (Macaca arctoides). J. Endocr. 111, 83-90.

Fraser, H.M., Sandow, J., Seidel, H. \& von Rechenberg, W. (1987) An implant of a gonadotropin releasing hormone agonist (buserelin) which suppresses ovarian function in the macaque for 3-5 months. Acta endocr., Copenh. 115, 521-527.

Fraser, H.M., Robertson, D.M. \& de Kretser, D.M. (1989) Immunoreactive inhibin concentrations in serum throughout the menstrual cycle of the macaque: suppression of inhibin during the luteal phase by treatment with an LHRH antagonist. J. Endocr. 121, R9-R12.

Glasier, A., Thatcher, S.S., Wickings, E.J., Hillier, S.G. \& Baird, D.T. (1988) Superovulation with exogenous gonadotropins does not inhibit the luteinizing hormone surge. Fert. Steril. 49, 81-85.

Land, R.B., Morris, B.A., Baxter, G., Fordyce, M. \& Forster, J. (1982) Improvement of sheep fecundity by treatment with antisera to gonadal steroids. $J$. Reprod. Fert. 66, 625-634.

Littman, B.A. \& Hodgen, G.D. (1984) Human menopausal gonadotropin stimulation in monkeys: blockade of the luteinizing hormone surge by a highly transient ovarian factor. Fert. Steril. 41, 440-447.

McLachlan, R.I., Robertson, D.M., Healy, D.L., Burger, H.G. \& de Kretser, D.M. (1987) Circulating immunoreactive inhibin levels during the normal human menstrual cycle. J. clin. Endocr. Metab. 65, 954-961.
McLachlan, R.I., Robertson, D.M., Healy, D.L., de Kretser, D.M. \& Burger, H.G. (1986) Plasma inhibin levels during gonadotrophin-induced ovarian hyperstimulation for IVF: a new index of follicular function? Lancet, 1233-1234.

Messinis, I.E. \& Templeton, A.A. (1987) Endocrine and follicle characteristics of cycles with and without endogenous luteinizing hormone surges during superovulation induction with pulsatile follicle-stimulating hormone. Hum. Reprod. 2, 11-16.

Messinis, I.E. \& Templeton, A.A. (1989) Pituitary response to exogenous LHRH in superovulated women. J. Reprod. Fert. 87, 633-639.

Robertson, D.M., Giacometti, M., Foulds, M., Lahnstein, J., Goss, N.H., Hearn, M.T.W. \& de Kretser, D.M. (1989) Isolation of inhibin $\alpha$-subunit precursor proteins from bovine follicular fluid. Endocrinology 125, 214l-2149.

Robertson, D.M., Tsonis, C.G., McLachlan, R.I., Handelsman, D.L., Leask, R., Baird, D.T., McNeilly, A.S., Hayward, S., Healy, D.L., Findlay, J.K., Burger, H.G. \& de Kretser, D.M. (1988a) Comparison of inhibin immunological and in vitro biological activities in human serum. J. clin. Endocr. Metab. $119,438-443$.

Robertson, D.M., Hayward, S., Irby, D., Jacobsen, J., Clarke, L., McLachlan, R.I. \& de Kretser, D.M. (1988b) Radioimmunoassay of rat serum inhibin: changes after PMSG stimulation and gonadectomy. Molec. cell. Endocrinol. 58, 1-8.

Schenken, R.S. \& Hodgen, G.D. (1983) Follicle stimulating hormone induced ovarian hyperstimulation in monkeys: blockade of the luteinizing hormone surge. J. clin. Endocr. Metab. 57, 50-55.

Stillman, R.J., Williams, R.F., Lynch, A. \& Hodgen, G.D. (1983) Selective inhibition of follicle stimulating hormone by porcine follicular fluid extracts in the monkey: effects on midcycle surges and pulsatile secretion. Fert. Steril. 40, 823-828.

Tsonis, C.G., Messinis, I.E., Templeton, A.A., McNeilly, A.S. \& Baird, D.T. (1988) Gonadotropic stimulation of inhibin secretion by the human ovary during the follicular and early luteal phase of the cycle. $J$. clin. Endocr. Metab. 66, 915-921.

Received 4 September 1989 